\title{
Alpine cattle management during the Bronze Age at Ramosch-Mottata, Switzerland
}

Thomas Reitmaier ${ }^{\mathrm{a},}{ }^{*}$, Thomas Doppler ${ }^{\mathrm{b}}$, Alistair W. G. Pike ${ }^{\mathrm{c}}$, Sabine Deschler-Erb ${ }^{\mathrm{b}}$, Irka Hajdas ${ }^{\mathrm{d}}$, Christoph Walser ${ }^{\mathrm{a}}$, Claudia Gerling ${ }^{\mathrm{b}}$

${ }^{a}$ Archaeological Service of the Canton of Grisons, Loestrasse 26, CH-7001 Chur, Switzerland thomas.reitmaier@adg.gr.ch

${ }^{\mathrm{b}}$ University of Basel, Institute of Prehistory and Archaeological Science, Spalenring 145, CH-4055

Basel, Switzerland

${ }^{\mathrm{c}}$ Faculty of Humanities, Department of Archaeology, University of Southampton, Avenue Campus, Highfield Southampton, SO17 1BF, United Kingdom

${ }^{\mathrm{d}}$ ETH Zürich, Laboratory of Ion Beam Physics, HPK H25, Otto-Stern-Weg 5, CH-8093 Zürich, Switzerland

*Corresponding author: Thomas Reitmaier

\section{Keywords}

Prehistory; Alps; mobility; radiocarbon chronology; strontium isotopes; LA-MC-ICP-MS

\section{Abstract}

Based on a series of new radiocarbon dates we examine the vertical mobility of cattle in the Alps by means of strontium isotope analysis on samples from the prehistoric settlement of Ramosch-Mottata (Canton of Grisons, Switzerland). By identifying variations in the strontium isotope ratios of highcrowned cattle molars, we investigate the seasonal use of alpine pastures (vertical transhumance) and changes in cattle husbandry practices between the early and later stages of the site's occupation. Combined with the evidence of multiple high-altitude sites, indications of dairying and ethnoarcheological observations, we see an economic shift and a reorganization of domestic animal exploitation from the early to the late Bronze/early Iron Age in the Alps.

\section{Introduction}

Nothing seems more natural in the Central European Alps than using the widespread high meadows for pasturing sheep, goats, cattle and horses in the summer months. Lush grassland, grazing animals, aromatic mountain cheese - many elements of the local alpine culture originated a long time ago and still characterize Switzerland`s identity today, although implying a distorted picture of the social reality (Weiss, 1992). The question of the beginnings of alpine summer farming has long been discussed (Frödin, 1940; Gleirscher, 1985; Gleirscher, 2010) and the debate has gained new 
momentum particularly in the past 25 years, fueled by the discovery of the Tyrolean Iceman Ötzi. This icon of alpine archeology and best manifestation of early vertical mobility (Egg and Spindler, 2009; Kutschera and Müller, 2003; Lippert et al., 2007; Oeggl et al., 2007; Oeggl et al., 2009), has repeatedly been associated with "vertical transhumance" (Spindler, 2005). However, despite extensive surveys over the past 25 years, no tangible archeological evidence has been found to support this theory (Gleirscher, 1997; Festi et al., 2014; Putzer and Festi, 2014; Putzer et al., 2016). Nevertheless, archeobiological surveys (Moe and van der Knaap, 1990), single finds at high altitudes and field name research have substantially contributed to the indexing of prehistoric alpine pastoralism in Switzerland. These works have provided a more detailed record of the various incentives that have driven humans up into the mountains for millennia, i.e. the sourcing of raw materials, transalpine trade and transport, hunting and gathering, conflicts, religion and pastoralism (Curdy et al., 2003; Curdy, 2007; Moe et al., 2007; Hess et al., 2010; Reitmaier, 2012; Patzelt, 2013; Alther, 2014; Walsh et al., 2014; Fedele, 2015; Giguet-Covex et al., 2015; Hafner, 2015; Schwörer et al., 2015).

Pastoralism is a distinct form of human subsistence in which domestic animals play a predominant role in the shaping of the economic and cultural lives of the people who depend on them. It is both a land use strategy and a system of animal production. There is a (world-)wide spectrum of different forms of pastoralism, due to a range of factors that can include the quantitative and qualitative characteristics of herds, the extent and range of mobility, the type of agricultural products, environmental and ecological aspects of the region and the extent of ties with an external market (Arnold and Greenfield, 2004; Arnold et al., 2013). The seasonal vertical movement of livestock between pastures at different altitudes is a highly specialized economic system and its adoption has important implications for a community's social-political structure, practices and cultural ideology in marginal highlands (Greenfield, 2010).

Few regions in Europe are as strongly associated with pastoralism and alpine animal husbandry as the Swiss-Austrian mountains. The question as to whether cattle were already being pastured in alpine meadows in the Engadine region, Switzerland, in the $2^{\text {nd }}$ and $1^{\text {st }}$ millennia BC was first asked more than 30 years ago. In her pioneering study on prehistoric sites in the Lower Engadine, StaufferIsenring $(1983,128)$ called for systematic research of prehistoric herding. Over the past 10 years various researchers have responded to this call by launching an interdisciplinary study on the development of alpine animal husbandry in the Silvretta Alps (Switzerland/Austria; Reitmaier et al., 2013). The Silvretta mountain range is located in the central eastern Alps and stretches across an area of c. $770 \mathrm{~km}^{2}$. This region remained completely devoid of any archeological evidence until 2007 , when systematic surveys started to reveal more than 200 archeological sites covering a period of 11 millennia. Amongst them a large number of high-alpine features (above $2000 \mathrm{~m}$ a.s.l.) were discovered. Besides the Mesolithic and Neolithic sites (Cornelissen and Reitmaier, 2016), a considerable number of Bronze Age structures are of particular interest with regard to the question of 
livestock and pastoral economy. They suggest that alpine pastures were used from the late $3^{\text {rd }}$ millennium BC onwards (Reitmaier, 2012). Palynological and paleoethnobotanical analyses highlight a distinct increase in human and domestic animal impact, with a fundamental transformation of the landscape at the transition to the $2^{\text {nd }}$ millennium BC (Dietre et al., 2014, 2016; Kothieringer et al., 2015). Apophytes and spores of coprophilous fungi are clear indicators for pasturing on alpine meadows during the Bronze Age and hint at grazing pressure. Particularly important in relation to alpine pastoralism are the first permanent buildings to emerge in the Silvretta Alps, from the early $1^{\text {st }}$ millennium BC onwards. Three dry-stone structures were identified as the remains of cattle/sheep pens (Fimba Valley/Val Fenga, Las Gondas, $2360 \mathrm{~m}$ a.s.1.; Tasna Valley/Val Tasna, $2060 \mathrm{~m}$ a.s.1.) and an alpine hut (Fimba Valley/Val Fenga, $2283 \mathrm{~m}$ a.s.l.). They were dated by radiocarbon measurements on charcoals from pits (Tab. 1, site no. 6, 8 and 10) and by typological assessment of ceramic finds, indicating that they were used during the late Bronze/early Iron Age (Reitmaier, 2012, fig. 10). The pottery suggested both a chronological and a functional connection between the high-altitude structures and settlements in the valley (e.g. Ramosch-Mottata, 1517 m a.s.l.; Ardez-Suotchastè, 1521 m a.s.l.; Guarda-Muot Pednal, 1696 m a.s.1.), which implies repeated long-term stays in the alpine pasture areas, with food supply and food production. This is supported by biochemical analyses of late Bronze and early Iron Age pottery attesting to local processing of milk and indicating a fundamental change in alpine animal husbandry (Carrer et al., 2016). All these lines of evidence suggest an established seasonal valley-alp system, as known from historical sources (Weiss, 1992).

An important part of such a system is the vertical movement of livestock to high-altitude meadows in summer and lowland pastures in winter. Isotopic analysis offers a systematic approach to investigating animal management and herding systems in general (e.g. Pearson et al., 2007; Knipper, 2011; Henton, 2012; Makarewicz and Tuross, 2012) and to tracing faunal mobility in mountain regions in particular (Valenzuela et al., 2016). A useful and well-established method is strontium isotope analysis, in particular when measured by high-resolution laser ablation multi-collector inductively coupled plasma mass spectrometry (LA-MC-ICP-MS). Strontium isotope analysis is based on the fact that strontium isotopes, i.e. the ratio of ${ }^{87} \mathrm{Sr}$ to ${ }^{86} \mathrm{Sr}$, vary according to geology, i.e. to differences in the age and composition of the bedrock (Faure and Powell, 1972; Ericson, 1985). Due to processes of erosion, the characteristic ${ }^{87} \mathrm{Sr} /{ }^{86} \mathrm{Sr}$ signature of the local geology is passed on to soil and plants and then via the food chain to animals and humans (Bentley, 2006). It is incorporated into hard tissues such as tooth enamel, where it substitutes calcium in the hydroxyapatite mineral. This happens at the time when tooth enamel is formed in growing animals and does not substantially change later (Julien et al., 2012). Enamel is relatively resistant to physical and chemical contamination due to its composition (Zazzo et al., 2005; Burton, 2008), although the degree of enamel diagenesis is unclear and has lately been under discussion (e.g. Zazzo, 2014). Nevertheless, cattle tooth enamel is a good proxy for the locally distinct strontium signal of the underlying geology where the animal was grazing at the time of tooth 
formation and tooth enamel mineralization. Cattle have high-crowned (hypsodont) teeth, which form sequentially from the cusp of the crown to the cervix (Hillson, 2005). Second permanent molars (M2) in cattle mineralize between the ages of approximately 1 month and 12/13 months, while third permanent molars (M3) mineralize from the age of 9/10 months to 23/24 months (Brown et al., 1960; Beasley et al., 1992). Hence, sampling of the second and third permanent molars of cattle provides isotopic insight into the first two years of the animals' lives. However, the growth rate of tooth enamel is probably non-uniform and there may be alternating periods of faster and slower enamel growth (Bendrey et al., 2015). Moreover, the isotope information available may cover a shorter period than two years, depending on the degree of tooth abrasion, which is subject amongst other things to the environmental conditions, the age of the animal at death and its fodder (Grant, 1978).

This paper examines mobility patterns of Bronze Age cattle in the Alps by applying strontium isotope analysis to samples from the prehistoric settlement of Ramosch-Mottata (Canton of Grisons, Switzerland). Our research focuses on i) the identification of variations in the strontium isotope ratios of high-crowned molars suggesting seasonal changes of pastures and ii) the identification of chronological changes in cattle husbandry practices between the early and later stages of the site's occupation.

\section{Environmental and archeological setting}

Ramosch-Mottata is located in the Lower Engadine Valley in the Canton of Grisons, Switzerland (Fig. 1). The altitude of the valley bottom varies between $1015 \mathrm{~m}$ a.s.l. at Martina in the east and $1475 \mathrm{~m}$ a.s.l. at Zernez in the west. The valley is shaped by the River Inn and surrounded by mountains reaching altitudes of $3400 \mathrm{~m}$ a.s.l. but easily accessible from different directions. A number of prehistoric settlements in the Lower Engadine have been excavated, albeit by amateurs and at a rather early date. The oldest sites dated from the early and middle Bronze Age (c. 2200-1350 BC) and were more or less continuously occupied until the late Iron Age (c. 400-15 BC). An interesting phenomenon in this area is the "Laugen-Melaun" group (Stauffer-Isenring, 1983; Gleirscher, 1992) which began to emerge in the early phase of the late Bronze Age (Bz D/Ha A1; c. 1350-1130 BC) and is interpreted as representing immigration from Northern Italy.

The hilltop settlement of Ramosch-Mottata (1517 m a.s.l.) has a very distinct position in the prehistoric cultural landscape of the Lower Engadine. Discovered in the 1950s and partially excavated in several campaigns (Frei, 1959), the site was the starting point for the systematic search for seasonal economic activities in the upland's prehistory. The permanent settlement is characterized by its location near terraced fields, highly suitable for farming (Raba, 1996), its favorable climate and, in particular, its outstanding position on an important inner- and transalpine trade route (Planta, 1987).

The main objective of the excavations carried out some 60 years ago was to establish a relativechronological framework for the inner alpine Bronze and Iron Ages based on pottery typology 
(Stauffer-Isenring, 1983), although radiocarbon dating, in its infancy, had yielded rough absolute dates for each of the stratigraphic layers (Gfeller et al., 1961). The excavators recovered a considerable quantity of animal bones (> 10,000 fragments) from five layers (Bronze Age, Melaun III, Melaun II, Melaun I, Fritzens-Sanzeno). Despite a brief report (Würgler, 1962), no detailed archeozoological investigation (i.e. with regard to harvest profiles or slaughter ages) has been carried out to date. It is clear, however, that the keeping of livestock, mainly sheep, goats and cattle, played an important role in the Bronze and Iron Age economic system at Ramosch-Mottata.

The geology around the site is highly varied (SBL, 2008, 2014). The area surrounding the settlement and the Sinestra Valley/Val Sinestra which runs towards the north (Fig. 1) are geologically comprised of Quaternary moraine, flysch (Tertiary/Cretaceous) and chalk (Jurassic/Cretaceous). Facing the Inn Valley, granites of the Tasna nappe (Cambrian) also crop out at the site along a stretch c. $2 \mathrm{~km}$ in length and $400 \mathrm{~m}$ in width. Paleozoic rocks (granite, gneiss, amphibolite) are widespread on the opposite side of the River Inn. The Fimba Valley/Val Fenga, north of Ramosch-Mottata, is characterized by flysch, partly covered by moraine. Further north, towards the Paznaun Valley there is again Paleozoic geology. Given the different ages and compositions of the rocks, one would expect highly varied ${ }^{87} \mathrm{Sr} /{ }^{86} \mathrm{Sr}$ ranges for the different geological units (Faure and Powell, 1972). Although compositions of granites and gneisses are quite variable, they have strontium isotope signatures > 0.7100 (Dickin, 1997, 490; Kutschera and Müller, 2003). Soil leachates from regions predominantly composed of gneisses and phyllites in the Austrian and Italian Alps, analyzed as part of the Tyrolean Iceman project, yielded ${ }^{87} \mathrm{Sr} /{ }^{86} \mathrm{Sr}$ values > 0.7200 (Kutschera and Müller, 2003; Müller et al., 2003). The basement rock in the Black Forest in south-western Germany consists of granites and gneisses from the Paleozoic. Samples from these geological formations have yielded ${ }^{87} \mathrm{Sr} /{ }^{86} \mathrm{Sr}$ values $>0.7100$ and very often even significantly higher, including the samples that reflect the biologically available strontium (Bentley and Knipper, 2005). In the same region, Oelze and her colleagues found average ${ }^{87} \mathrm{Sr} /{ }^{86} \mathrm{Sr}$ values of $0.7153 \pm 0.0029(1 \sigma, \mathrm{n}=9)$ for modern reference samples in regions where gneiss predominates and of $0.7145 \pm 0.0031(1 \sigma, \mathrm{n}=8)$ for samples from granite (Oelze et al., 2012).

Significantly lower ${ }^{87} \mathrm{Sr} /{ }^{86} \mathrm{Sr}$ ratios can be expected for the areas with Jurassic and Cretaceous geology. Ranges of between c. 0.7070 and 0.7086 have been suggested for Jurassic limestone (Veizer et al., 1999). Modern reference samples from limestone regions in south-western Germany average $0.7077 \pm$ $0.0005(1 \sigma, \mathrm{n}=13)$ (Oelze et al., 2012), and those from Cretaceous chalk on the British Isles average $0.7082 \pm 0.0004(1 \sigma, \mathrm{n}=9$, plants) and $0.7079 \pm 0.0001(1 \sigma, \mathrm{n}=5$, water) (Evans et al., 2010). Areas where Quaternary glacial deposits predominate are expected to have somewhat higher strontium isotope ratios. Oelze found that samples from several locations in regions where glacial moraine predominates in south-western Germany averaged ${ }^{87} \mathrm{Sr} /{ }^{86} \mathrm{Sr}$ values of between $0.7086 \pm 0.0006(1 \sigma$, $\mathrm{n}=4), 0.7089 \pm 0.0002(1 \sigma, \mathrm{n}=4)$ and $0.7105 \pm 0.0011(1 \sigma, \mathrm{n}=4)$ (Oelze et al., 2012). This matched the values measured in pigs' teeth $(0.7097 \pm 0.0008(1 \sigma, \mathrm{n}=8))$ from the pre-alpine lowlands of prehistoric 
southern Germany, where marine sediments are overlaid by glacial moraine, freshwater sediments and loess deposits, as analyzed by Bentley and Knipper (2005). However, strontium isotope ratios vary significantly, even in samples from the same types of rock or of the same date, indicating that comparable results from other regions may only be treated as rough indications. We may, however, conclude that the area around Ramosch-Mottata exhibits distinct differences with regard to expected ${ }^{87} \mathrm{Sr} /{ }^{86} \mathrm{Sr}$ signatures, which allows us to distinguish between pasture grounds overlying diverse geologies.

\section{Material and Methods}

Teeth and bone of 15 cattle from different stratigraphic layers were selected for radiocarbon AMS measurements at the Laboratory for Ion Beam Physics, Swiss Federal Institute of Technology Zurich (ETH), Switzerland (Tab. 2) and for strontium isotope analysis at the National Oceanography Centre Southampton (NOCS), UK (Tab. 3).

Teeth and bone were sampled at the Institute of Prehistory and Archaeological Science (IPAS), University of Basel, Switzerland. Age at death was determined following an established and modified method based on Habermehl (1975). In-depth archeozoological investigation guaranteed that each animal was only sampled once. Based on availability and preservation, we sampled the enamel of one second permanent molar (M2) and 14 third permanent molars (M3). The surface of each tooth was carefully cleaned using a dental burr and hand drill. A longitudinal enamel section of c. $2 \mathrm{~mm}$ thickness representing the complete available growth axis of the tooth was cut using a diamondimpregnated dental disk. The enamel section was fixed laterally on a round PTFE mount and embedded in epoxy resin (Biodur® E12 + Biodur ${ }^{\circledR}$ E1 hardener 100:28). After 12 hours in a vacuum, the resin was hardened in an oven at $35^{\circ} \mathrm{C}$ for 48 hours. The surface of the resin was ground to reveal the surface of the enamel section and polished manually using successive grades of $\mathrm{SiC}$ paper down to P1200 grit. The sample mounts were then transferred to NOCS for Sr isotope analysis. The analysis was performed on a Thermo Fisher Neptune multi collector ICP-MS with a New Wave $193 \mathrm{~nm}$ ArF homogenized excimer laser, using the oxide reduction technique developed by De Jong (De Jong et al., 2010; De Jong, 2013, Lewis et al., 2014) which manipulates the plasma conditions to reduce the molecular interference on ${ }^{87} \mathrm{Sr}$ of ${ }^{40} \mathrm{Ca}^{31} \mathrm{P}^{16} \mathrm{O}^{+}$, which is a primary constituent of the enamel matrix. Other potential problems come from double-charged rare earth elements which give mass to charge ratios of between 84 and 88 , calcium-calcium and calcium-argide dimers which can interfere with ${ }^{84} \mathrm{Sr}$, ${ }^{86} \mathrm{Sr}$ and ${ }^{88} \mathrm{Sr}$, as well as potential ${ }^{87} \mathrm{Rb}$ and ${ }^{86} \mathrm{Kr}$ interferences. In addition to oxide reduction in the plasma (monitored as ${ }^{254}(\mathrm{UO}){ }^{+} \rho^{238} \mathrm{U}^{+}$), teeth which have significant rare earth concentrations are considered diagenetically altered and are thus rejected. We correct for the ${ }^{86} \mathrm{Kr}$ using an on-peak gas blank and for rubidium interference using the natural ${ }^{87} \mathrm{Rb} /{ }^{85} \mathrm{Rb}$ ratio of 0.385617 . A small positive offset from known ${ }^{87} \mathrm{Sr} /{ }^{86} \mathrm{Sr}$ values is usually observed, because the oxide interference is not completely eliminated, but is normally well within the precision of a typical measurement. Time series 
of strontium isotope ratios are obtained as continuous data by moving the tooth along its growth axis (at 20 or $25 \mu \mathrm{ms}^{-1}$ depending on the size of the tooth) as the laser pulses with a repetition rate of $15 \mathrm{~Hz}$ and spot size of $150 \mu \mathrm{m}$, giving a fluence of c. $8.6 \mathrm{Jcm}^{-2}$. The laser track was positions to be in the centre of the enamel thickness to avoid areas close to the edges (i.e. the outer surface and dentineenamel junction) which would be affected most by diagenesis (Wilmes et al. 2016). Before analysis, the laser track was cleaned using an identical repetition rate and spot size but a speed of $100 \mu \mathrm{ms}^{-1}$. A mean offset of laser ablation analysis results against TIMS values of $+44 \pm 33 \mathrm{ppm}(1 \sigma)$ was determined from 279 analyses of an in-house ashed bovine pellet standard (BP), carried out over 18 months, with three repeats after every third sample. This is about the same order as the smallest within-tooth variation, but well within the variation between the majority of the teeth, and is therefore considered insignificant to our interpretation of the isotopes. In the absence of suitable references for the biologically available strontium from the site, we used dentin as a proxy for the on-site signature. The dentin samples were analyzed for ${ }^{87} \mathrm{Sr} /{ }^{86} \mathrm{Sr}$ using LA-MC-ICP-MS spot measurements. Measurements were performed with a spot size of $150 \mu \mathrm{m}$ and a laser pulse rate of $10 \mathrm{~Hz}$ for 60 seconds. Before these measurements each spot was cleaned for 5 seconds using an identical spot size but a repetition rate of $15 \mathrm{~Hz}$.

\section{Results and Discussion}

The enamel ( $\mathrm{n}=15$ ) shows ${ }^{87} \mathrm{Sr} /{ }^{86} \mathrm{Sr}$ values ranging from 0.70608 to 0.72070 with an average of $0.70933 \pm 0.00302(1 \sigma)$ (Figs. 2 and 3; Tab. 3). Ignoring the highly radiogenic values of RMO 19, ${ }^{87} \mathrm{Sr} /{ }^{86} \mathrm{Sr}$ measurements average $0.70843 \pm 0.00053(1 \sigma)$ and range from 0.70608 to 0.71138 . Ten dentin samples average $0.70847 \pm 0.00117(2 \sigma)$ (Tab. 3). Ignoring the distinct outlier RMO 19, the dentin has an average ${ }^{87} \mathrm{Sr} /{ }^{86} \mathrm{Sr}$ value of $0.70829 \pm 0.00021(2 \sigma)$. A Corelation between ${ }^{87} \mathrm{Sr} /{ }^{88} \mathrm{Sr}$ and $1 / \mathrm{Sr}_{\text {(concentration) }}$ is taken by some authors to indicate the presence of diagenetic Sr. This would be true if diagenetic incorporation of strontium were additive rather than by exchange with biogenic $\mathrm{Sr}$, and if there were no variation in bioavailable $\mathrm{Sr}$ concentrations within different $\mathrm{Sr}$ isotope catchments. Diagenetic exchange with biogenic Sr would alter ${ }^{87} \mathrm{Sr} /{ }^{88} \mathrm{Sr}$ vaues without generating a trend of these values with $1 / \mathrm{Sr}_{\text {(concentration) }}$ and co-variation in bioavailable $\mathrm{Sr}$ concentrations with ${ }^{87} \mathrm{Sr} /{ }^{88} \mathrm{Sr}$ has the potential to generate these trends without any diagenetic Sr being present (e.g. see Montgomery 2010). Nevertheless, Fig. *** shows our Sr isotope values plotted against $1 / \mathrm{Sr}$ using ${ }^{88} \mathrm{Sr}$ beam size (V) as a proxy for Sr concentration. There is no significant correlation between $1 / \mathrm{Sr}$ and ${ }^{87} \mathrm{Sr} /{ }^{86} \mathrm{Sr}$ in either the enamel or the dentine $\left(r^{2} \leq 0.01\right)$ though it is clear that $\mathrm{Sr}$ isotopic values in dentine are different from and less variable than in the enamel and, in all but one case, have higher $\mathrm{Sr}$ concentrations. This is strongly suggestive of $\mathrm{Sr}$ diagenesis in the dentine. For the enamel, the more radiogenic enamel values are associated with lower $\mathrm{Sr}$ isotope concentrations, which may be suggestive of diagenesis, though we cannot rule out that the radiogenic Sr catchments have lower bioavailable Sr concentrations than the more radiogenic ones. Nevertheless, we take a cautious approach. 
261 Although it has been shown that enamel is not entirely resistant to post-mortal influences (e.g. Zazzo,

262

263

264

265

266

267

268

269

270

271

272

273

274

275

276

277

278

279

280

281

282

283

284

285

286

287

288

289

290

291

292

293

294

295

296 2014 Fig *** shows, as expected, that dentin is far more sensitive to diagenetic alteration. It is expected to give ${ }^{87} \mathrm{Sr} /{ }^{86} \mathrm{Sr}$ values between the enamel values and those of $\mathrm{Sr}$ in the groundwater of the burial environment (e.g. Budd et al., 2000;; Hoppe et al., 2003; Nehlich et al., 2009), though is not uncommon for dentine to have fully equilibrated with the burial groundwater i.e. for the biogenic $\mathrm{Sr}$ signal to be completely overprinted (e.g. Chiaradia et al, 2003, Haak et al. 2008). Where this is not the case, patterns in the paired enamel-dentine values can give an indication of the diagenetic endmember (i.e. the $\mathrm{Sr}$ in the burial environment). Fig. **** shows that, with the exception of sample RMO 13, the dentine values tend towards a ${ }^{87} \mathrm{Sr} /{ }^{88} \mathrm{Sr}$ of c. 0.7083 which we take to be the $\mathrm{Sr}$ in the burial groundwater. From this, use the method of Budd et al. (2000) to calculate the degree of Sr uptake or replacement required to account for the difference between the enamel and dentine, and which ranges from 25 to $83 \%$ with a mean of $58 \%$. While the method of Budd et al. assumes the enamel retains biogenic Sr value, Hoope et al. (2003) observed a c. 25\% diagenetic strontium in enamel samples from environments where bones had incorporated c. $80 \%$ diagenetic strontium. Assuming the relative effects of diagenesis are similar between bone and dentine, and noting that our estimates of the degree of diagenesis in dentine is lower than those observed in bones by Hoppe et al., and our use of laser ablation that ensured only the centre of the enamel is sampled, we model the effects of $25 \%$ diageneic overprinting of $\mathrm{Sr}$ in the enamel as the worst case scenario (see below).

The 15 radiocarbon dates on bone collagen range from 1744 cal BC to 801 cal $\mathrm{BC}(2 \sigma)$, covering a time span between the early and very late Bronze/early Iron Age.

\section{Chronological classification of the cattle remains}

Würgler (1962) based his analysis and interpretation of the animal bones on a stratigraphy, which had been divided into five layers (Bronze Age; Melaun III; Melaun II, Melaun I; Fritzens-Sanzeno). This local, inner-alpine and relative-chronological sequence was later correlated by Stauffer-Isenring (1983) with the chronologies commonly used north and south of the Alps. Following her correlation, the (inner-alpine) early Bronze Age (Bz A) dates from 2200 to c. $1550 \mathrm{BC}$, the middle Bronze Age (Bz B, C1, C2) from 1550 to 1350 BC, the late Bronze Age with Laugen-Melaun A (Bz D, Ha A1/A2, B1) from c. 1350 to 1050/1000 BC and with Laugen Melaun B (Ha B1/B2, B3) up to around 800 BC. The phase Laugen-Melaun C is roughly equivalent to the early Iron Age (Hallstatt; Ha C1-D2/D3, 800 BC to c. 500 BC), whilst Fritzens-Sanzeno can be equated with the late Iron Age (La Tène). The radiocarbon dates obtained represent the early Bronze Age (RMO 19, 18), the late Bronze Age (RMO $15,14,11,6,2,1,7,5,10,13)$ and possibly the early Iron Age (RMO 9, 16, 7) (Fig. 5). The chronological correlation serves as a framework for the interpretation of the strontium isotope ratios. The comparison between the absolute-chronological order of our samples and the sequence of the 
animal bones as based on the stratigraphy according to Würgler (Tab. 2) results in discrepancies, which suggest that the original relative-chronological order of the material from Ramosch-Mottata must be viewed with circumspection.

\section{Land use and cattle mobility at Ramosch-Mottata}

Without a detailed study of bioavailable Sr locally and from more distant potential pastures, it is difficult to construct a detailed pattern of the movements of cattle, but we nevertheless observe a difference between the mobility patterns of cattle from the early vs. the late stage of the site's occupation. The most common pattern, represented by all samples that dated from later periods $\left(12^{\text {th }}-\right.$ $9^{\text {th }}$ centuries BC) with the exception of RMO 7, showed Sr values that centre on the value we estimated for the $\mathrm{Sr}$ value of the burial environment (0.7083) and with very little within tooth variation. This is in contrast to the chronologically oldest animals (RMO 19, 18), dated to the $18^{\text {th }}-16^{\text {th }}$ centuries BC, which yielded ${ }^{87} \mathrm{Sr} /{ }^{86} \mathrm{Sr}$ patterns which lay completely or at least largely outside the onsite ${ }^{87} \mathrm{Sr} /{ }^{86} \mathrm{Sr}$ (Fig. 2), and showed higher degrees of within tooth variability. RMO 15 and RMO 14, which may date from as early as the $13^{\text {th }}$ century BC, yielded values that clearly lay outside of the onsite strontium isotope range (RMO 14) or only partially coincided with it (RMO 15). The grouping of cattle according to this scheme is not affected by an assumption of $25 \%$ diagenesis (Fig. ***) .

Both old geologies which are expected to result in high ${ }^{87} \mathrm{Sr} /{ }^{86} \mathrm{Sr}$, and younger geological units where less radiogenic ${ }^{87} \mathrm{Sr} /{ }^{86} \mathrm{Sr}$ is expected can be found in the immediate surroundings of the settlement. It is therefore tempting to interpret both the more radiogenic values with more dynamic ${ }^{87} \mathrm{Sr} /{ }^{86} \mathrm{Sr}$ curves of the early phase and the less radiogenic, more static patterns of the later phase as year-round grazing in the vicinity of the site. However, the topographical situation of the site suggests that good pastureland was limited and that the animals could be kept near the settlement for a short period of the year at most. Furthermore, it was certainly necessary to move cattle to lower altitudes during winter (Niederstätter, 1999), when snowfall was intense at $1500 \mathrm{~m}$ a.s.l., all the more since we do not have evidence for stabling in Ramosch-Mottata. It is therefore much more likely that all cattle were pastured, at least for part if not all of the year, at a distance from the settlement. Topographically favorable pasture grounds with potentially very high ${ }^{87} \mathrm{Sr} /{ }^{86} \mathrm{Sr}$ ratios (due to early geological formations) can be found just a few kilometers from Ramosch, to the south on the other side of the River Inn, to the east around Lake Reschen, which can be reached via the Schlinig or Reschen Passes, or to the north in the Paznaun Valley, which can be reached via the Fimba Valley/Val Fenga or by following the River Inn downstream (SBL, 2008; Fig. 1). Keeping cattle on distant pastures may be linked to transhumance but also to an exchange of animals between different sites. Social links and networks between settlements can be important, for instance in ensuring access to pastureland, minimizing the effort that has to be put into animal husbandry, keeping herd sizes stable and maintaining a good supply of working animals (Ebersbach, 2002). The chronological differences in 
${ }^{87} \mathrm{Sr} /{ }^{86} \mathrm{Sr}$ patterns observed in the cattle samples suggest that a change in herding management occurred during the late Bronze Age (Fig. 2). From the $12^{\text {th }}$ century BC onwards, the ${ }^{87} \mathrm{Sr} /{ }^{86} \mathrm{Sr}$ values are consistent with the estimated burial groundwater value. If this value is representative of the local bioavailable $\mathrm{Sr}$, this would point to year-round pasture near the settlement or in regions with similar geology within a landscape that was characterized by more open areas, as evidenced by paleoenvironmental studies (Dietre et al., 2014; Kothieringer et al., 2015). Interestingly, the Fimba Valley/Val Fenga is characterized by a similar geology as the surroundings of Ramosch-Mottata and can be expected to show similar on-site ${ }^{87} \mathrm{Sr} /{ }^{86} \mathrm{Sr}$ values. This valley, only a 4 to 6 hours walk away, is particularly well suited for summer pasturing due to its location above the alpine tree line, with vast open areas that provide sufficient amounts of fodder even for large herds. How much pastureland would effectively have been required to feed the livestock at the time when Ramosch was settled remains unclear. This would have been a crucial factor in mobile animal husbandry (Ebersbach, 2002), however, for instance as part of a system that utilized pastureland at different altitudes and different times of the year (Reitmaier, 2010; Alther, 2014). Because (seasonal) mobility between similar geological units cannot be identified by means of strontium isotope analysis, we may not ascertain whether the ${ }^{87} \mathrm{Sr} /{ }^{86} \mathrm{Sr}$ patterns that coincide with the on-site isotopic signature of Ramosch-Mottata could also be explained by pasture grounds in the Fimba Valley/Val Fenga. Future analysis of oxygen isotope ratios, which primarily depend on climatic conditions, precipitation, geographic location and altitude (Dansgaard, 1964; Gat, 1980), will help to answer questions regarding, for instance, distinguishing between summer and winter pastures at varying altitudes. However, changes in the fodder or in pasture grounds, potentially linked to short-term mobility, are suggested by variations in the ${ }^{87} \mathrm{Sr} /{ }^{86} \mathrm{Sr}$ patterns of some of the individuals (RMO 7, 5, 13). Vertical mobility is further supported by the available archeological evidence, e.g. the first appearance of permanent stone-built structures (huts, pens), e.g. in the Fimba Valley/Val Fenga, as well as of dairy products in the Silvretta Mountains and in other parts of the Alps after 1000 BC (Curdy, 2007; Marzatico, 2007; Gleirscher, 2010; Hess et al., 2010; Patzelt, 2013; Putzer, 2009, 2013). It seems that claims to the available pastureland were more clearly asserted, resulting in the construction of permanent infrastructural buildings (Fig. 6B). We may assume that the livestock were now regularly being brought to pasture grounds which were in permanent ownership.

\section{Implications for the inner alpine economy in the Bronze Age}

This new and different strategy and hierarchy with regard to the perception and principle of territoriality (Kossack, 1992; Steiner, 2010; Walsh and Mocci, 2011) suggests a fundamental change in animal husbandry at the end of the $2^{\text {nd }}$ millennium $\mathrm{BC}$, as has also been proposed for other areas in the Alps, e.g. based on archeozoological data (Riedel and Tecchiati, 2001; Plüss, 2011; Bopp-Ito, 2012; Stopp, 2015). We link this shift to an immigration of people with a different cultural background (evidenced by pottery of the Laugen-Melaun group) from the late Bronze Age (Bz D/Ha A1) onwards. 
At a more advanced stage of the new influence, specifically at the transition from Laugen-Melaun A to Laugen-Melaun B (Ha B1 to Ha B2, around 1050/1000 BC), we identify the observed shift in cattle husbandry and land use. This shift was very probably linked to a change in animal product exploitation. The (ethno)archeological differentiation between the exploitation of primary and secondary animal products and their archeological (in)visibility in the Alps was recently discussed by Carrer (2015, 2016a, b). Basically, two pastoral strategies can be distinguished in the Alps: the exploitation of primary and secondary animal products. Besides dairying, the latter implies the use of wool, while meat, hide and bone were important primary products (Greenfield, 2010). The characterization of alpine pastoralism and transhumant shepherd sites, as described by Carrer, allows us to infer a differentiation between these two categories (Fig. 6). Non-dairy animals are allowed to move freely throughout the pasture grounds and search for available grazing areas (Fig. 6A).

Shepherds do not enclose the animals and a single herdsman can manage a flock of more than 1000 non-dairy sheep. As herders do not need to bring their animals back to a permanent seasonal site to milk them or produce any dairy products, their only focus is on grazing. There is therefore no need to select a location that suits their requirements and the herders usually spend their nights under rock shelters or even under trees. Higher mobility means much less archeological visibility, but greater variability in the mobility patterns. Dairying, on the other hand, requires hard work and a specialized working group. In order to maximize milk production and quality, herders are required to find the best and most accessible pastures. A herd of at most 150-200 sheep is kept in pens and permanent seasonal buildings are required for milk processing and storing the dairy products (Fig. 6B). These sites are usually placed in the middle of an appropriate grazing area to enable the herder to pasture his animals in the immediate surroundings. The choice of location is important and based on the evaluation of specific environmental features. As a result, seasonal mobility is much more uniform (Carrer, 2016a, b).

Assuming that Carrer's model can be transferred to large herbivores, we may use it to explain the different mobility patterns seen in the cattle from Ramosch-Mottata. The ${ }^{87} \mathrm{Sr} /{ }^{86} \mathrm{Sr}$ ratios in the samples from the early Bronze and an early stage of the late Bronze Age (RMO 19, 18, 15, 14) reveal that the cattle herds were more mobile (regarding the geology of grazing grounds) or herding management was more variable at that stage than in subsequent centuries. The geographical distribution of contemporary alpine sites throughout the Silvretta region (Fig. 6A) supports this hypothesis. These are modest camps under large boulders or open-air sites without any elaborate structures and with a complete absence of fragile ceramic vessels. We therefore assume that they were intended for occasional and short-term stays until the $12^{\text {th }}$ century $\mathrm{BC}$, when the situation started changing. Paleoenvironmental data in our study region attested to a fundamental transformation in the alpine landscape starting in the Bronze Age (Zoller and Erny-Rodman, 1994; Dietre et al., 2014, 2016; Kothieringer et al., 2015). Intensified human and animal impact on the natural environment has also been identified in many other alpine areas for the same period (Gobet et al., 2003; Tinner et al., 2005; 
Moe et al., 2007; Röpke et al., 2011; Röpke and Krause, 2013; Festi et al., 2014). The large-scale development is generally and consistently seen in conjunction with an intensive settling of the alpine valleys and an associated utilization of the treeless high pasture grounds (Nicolussi, 2012; Tinner and Theurillat, 2003). The exploitation of large raw material deposits (copper/salt) and an increased mobility in the $2^{\text {nd }}$ millennium BC may have made a significant contribution towards the expansion into marginal zones and a change in cattle management (Donat et al., 2006; Primas, 2009; Schibler et al., 2011; Walsh and Mocci 2011; Della Casa et al., 2015; Carrer et al., 2016). The Bronze and Iron Age sites in the Silvretta region support this notion of a sudden and intense human presence at high altitudes (Tab. 1), very probably linked to animal husbandry. The importance of pastoral activities is clearly emphasized by the secondary role of hunting (Würgler, 1962; Riedel and Tecchiati, 2001; Plüss, 2011; Stopp, 2015).

\section{Conclusion}

Based on new radiocarbon dates and high-resolution strontium isotope analysis (LA-MC-ICP-MS) we see a chronological shift in the vertical mobility patterns of prehistoric cattle from Ramosch-Mottata, Switzerland. We suggest a change in alpine animal management during the late Bronze Age, around the second half of the $12^{\text {th }}$ century BC. In combination with archeological structures at high altitudes (huts/pens), results from lipid analysis on potsherds (dairying) and evidence from paleoenvironmental proxy data (land use) in the Silvretta Alps, we consider our strontium isotope results to reflect the transition from primary to secondary product exploitation. This is consistent with the large-scale developments in the entire (Circum-)alpine region during the end of the $2^{\text {nd }}$ and the beginning of the $1^{\text {st }}$ millennium BC (Primas, 2009; Rageth, 2010; Migliavacca, 2015).

\section{Acknowledgment}

We thank the following colleagues for their support: Andy Milton, Isabel Aitken, Sandy Hämmerle and three anonymous reviewers who helped to substantially improve an earlier version of this manuscript. Research was funded by the Archaeological Service of the Canton of Grisons, Switzerland.

\section{References}

Alther, Y., 2014. Vertikal mobil. Ein Beitrag zum Verständnis alpiner Wirtschaftsformen in der Archäologie. Archäologie Graubünden, Sonderheft 3. Archäologischer Dienst Graubünden, Chur.

Arnold, E.R., Greenfield, H.J., 2004. A Zooarchaeological Perspective on the Origins of Vertical Transhumant Pastoralism and the Colonization of Marginal Habitats in Temperate Southeastern Europe. In: Mondini, M., Muñoz, S., Wickler, S. (Eds.), Colonisation, Migration, and Marginal Areas. Oxbow, Oxford, pp. 96-117. 
446 Arnold, E.R., Greenfield, H.J., Creaser, R.A., 2013. Domestic cattle mobility in early farming villages

447 in southern Africa: harvest profiles and strontium $\left({ }^{87} \mathrm{Sr} /{ }^{86} \mathrm{Sr}\right)$ isotope analyses from Early Iron Age

448 sites in the lower Thukela River Valley of South Africa. Archaeological and Anthropological Sciences

$449 \quad 5,129-144$.

450

451

Beasley, M.J., Brown, W.A.B., Legge, A.J., 1992. Incremental banding in dental cementum: methods

452 of preparation for teeth from archaeological sites and for modern comparative specimens. International

453 Journal of Osteoarchaeology 2, 37-50.

454

455

Bendrey, R., Vella, D., Zazzo, A., Balasse, M., Lepetz, S., 2015. Exponentially decreasing tooth

456 growth rate in horse teeth: implications for isotopic analyses. Archaeometry 57(6), 1104-1124.

457

458

Bentley, R.A., 2006. Strontium isotopes from the Earth to the archaeological skeleton: a review.

459

Journal of Archaeological Method and Theory 13, 135-187.

460

461

Bentley, R.A., Knipper, C., 2005. Geographical patterns in biologically available strontium, carbon

462 and oxygen isotope signatures in prehistoric SW Germany. Archaeometry 47, 629-644.

463

464

Bopp-Ito, M., 2012. Animal husbandry in the Bronze Age Alpine settlement "Savognin - Padnal",

465

466

467

468

469

470

471

472

473

474

475

476

477

478

479

480

481

Switzerland: a preliminary study. In: Lefèvre, C. (Ed.), Proceedings of the General Session of the 11th International Council for Archaeozoology Conference (Paris, 23-28 August 2010). BAR International Series 2354, 75-85.

Bronk Ramsey, C., 2013.

Bronk Ramsey, C., 2016.

Brown, W.A.B., Christofferson, P.V., Massler, M., Weiss, M.B., 1960. Postnatal tooth development in cattle. American Journal of Veterinary Research 21, 7-34.

Budd, P., Montgomery, J., Barreiro, B., Thomas, R.G., 2000. Differential diagenesis of strontium in archaeological human dental tissues. Applied Geochemistry 15, 687-694.

Burton, J., 2008. Bone chemistry and trace element analysis. In: Katzenberg, M.A., Saunders, S.R.

(Eds.), Biological Anthropology of the human skeleton, Second Edition. John Wiley \& Sons, Hoboken, NJ, pp. 443-460. 
483 Carrer, F., 2015. Herding Strategies, Dairy Economy and Seasonal Sites in the Southern Alps:

484 Ethnoarchaeological Inferences and Archaeological Implications. Journal of Mediterranean

485

486

487

488

489

490

491

492

493

494

495

496

497

498

499

500

501

502

503

504

505

506

507

508

509

510

511

512

513

514

515

516

517

518

Archaeology 28, 3-22.

Carrer, F., 2016a. Secondary products exploitation: preliminary ethnoarchaeological insights from alpine cases study. In: Biagetti, S., Lugli, F. (Eds.), The Intangible Elements of Culture in Ethnoarchaeological Research. Springer International Publishing, New York, pp. 115-124.

Carrer, F., 2016b. The 'invisible' shepherd and the visible dairyman: Ethnoarchaeology of alpine pastoral sites in the Val di Fiemme (eastern Italian Alps). In Collins J.R., Nicolis F. \& Pearce M. (Eds.), Summer Farms. Seasonal Exploitation of the Uplands from Prehistory to the Present. J.R. Collins Publications, Sheffield, pp. 97-107.

Carrer, F., Colonese, A.C., Lucquin, A., Guedes, E.P., Thompson, A., Walsh, K., Reitmaier, T., Craig, O.E., 2016. Chemical Analysis of Pottery Demonstrates Prehistoric Origin for High-Altitude Alpine Dairying. PLoS ONE 11(4): e0151442. doi:10.1371/journal.pone.0151442

Chiaradia, M., Gallay, A., Todt, W., 2003. Different contamination styles of prehistoric human teeth at a Swiss necropolis (Sion, Valais) inferred from lead and strontium isotopes. Applied Geochemistry 18, 353-370.

Cornelissen, M., Reitmaier, T., 2016. Filling the gap: Recent Mesolithic discoveries in the central and south-eastern Swiss Alps. Quaternary International 2016. doi:10.1016/j.quaint.2015.10.121

Curdy, P., 2007. Prehistoric settlement in middle and high altitudes in the Upper Rhone Valley (Valais-Vaud, Switzerland): A summary of twenty years of research. In: Della Casa, P., Walsh, K. (Eds.), Interpretation of Sites and Material Culture from mid-high altitude mountain environments. Proceedings of the 10th annual meeting of the European Association of Archaeologists 2004. Trento: Museo Tridentino di Scienze Naturali, pp. 99-108.

Curdy, P., Leuzinger-Piccand, C., Leuzinger, U., 2003. Zermatt Alp Hermettji et les cols secondaires du Valais. In: Besse, M., Stahl-Gretsch, L.-I., Curdy, P. (Eds.), ConstellaSion. Hommage à Alain Gallay. Cahiers d'Archéologie Romande 95. Musée cantonal d'archéologie et d'histoire, Lausanne, pp. 73-88.

Dansgaard, W., 1964. Stable isotopes in precipitation. Tellus 16, 436-468. 
520 Della Casa, P. Naef, L., Turck, R., 2015. Prehistoric copper pyrotechnology in the Swiss Alps:

521 Approaches to site detection and chaîne opératoire. Quaternary International 2015, 402, 26-34.

522 doi:10.1016/j.quaint.2015.08.037

523

524

525

526

527

528

529

530

531

532

533

534

535

536

537

538

539

540

541

542

543

544

545

546

547

548

549

550

551

552

553

554

555

De Jong, H.N., 2013. A Strontium Isotope Perspective on Subsistence Through Intra-tooth and Intersite Variation by LA-MC-ICP-MS and TIMS. PhD thesis. University of Bristol, Bristol, UK.

De Jong, H., Foster, G., Heyd, V., Pike, A.W.G., 2010. Further Sr isotopic studies on the Eulau multiple graves using laser ablation ICP-MS. In: Meller, H., Alt, K. (Eds.), Anthropologie, Isotopie und DNA - biografische Annäherung an namenlose vorgeschichtliche Skelette? Landesmuseum für Vorgeschichte, Halle (Saale), pp. 63-70.

Dickin, A.P., 1997. Radiogenic Isotope Geology. Cambridge University Press, Cambridge.

Dietre, B., Walser, C., Lambers, K., Reitmaier, T., Hajdas, I., Haas, J.N., 2014. Palaeoecological evidence for Mesolithic to Medieval climatic change and anthropogenic impact on the Alpine flora and vegetation of the Silvretta Massif (Switzerland/Austria). Quaternary International 353, 3-16.

Dietre, B., Walser, C., Kofler, W., Kothieringer, K., Hajdas, I., Lambers, K., Reitmaier, T., Haas, J.N., 2016. Neolithic to Bronze Age (4850-3450 cal. BP) fire management of the Alpine Lower Engadine landscape (Switzerland) to establish pastures and cereal fields. The Holocene, published online before print August 8, 2016. doi:10.1177/0959683616658523

Donat, P., Petrucci, G., Flügel, C., 2006. Fleischkonserven als Produkte römischer Almwirtschaft.

Schwarze Auerbergkeramik vom Monte Sorantri bei Raveo (Friaulisch-Julisch-Venetien,

Nordostitalien). Bayerische Vorgeschichtsblätter 71, 209-232.

Ebersbach, R., 2002. Von Bauern und Rindern. Eine Ökosystemanalyse zur Bedeutung der Rinderhaltung in bäuerlichen Gesellschaften als Grundlage zur Modellbildung im Neolithikum. Basler Beiträge zur Archäologie 15. Schwabe, Basel.

Egg, M., Spindler, K., 2009. Kleidung und Ausrüstung der kupferzeitlichen Gletschermumie aus den Ötztaler Alpen. Mann Eis 6= Monographien Römisch-Germanisches Zentralmuseum Mainz 77.

Ericson, J.E., 1985. Strontium isotope characterization in the study of prehistoric human ecology. Journal of Human Evolution 14, 503-514. 
557 Evans, J.A., Montgomery, J., Wildman, G., Boulton, N., 2010. Spatial variations in biosphere ${ }^{87} \mathrm{Sr} /{ }^{86} \mathrm{Sr}$

558 in Britain. Journal of the Geological Society 167, 1-4.

559

560 Faure, G., Powell, T., 1972. Strontium isotope geology. Springer, New York.

561

562

Fedele, F., 2015. Nuove date radiocarboniche per l'archeologia preistorica e storica

563

della valle Spluga: Pian dei Cavalli, Borghetto, Mottaletta. Clavenna 2014, 9-32.

564

565

Festi, D., Putzer, A., Oeggl, K., 2014. Mid and late Holocene land-use changes in the Ötztal Alps,

566 territory of the Neolithic Iceman “Ötzi.” Quaternary International 353, 17-33.

567

568

Frödin, J.O.H., 1940. Zentraleuropas Alpwirtschaft. Oslo: Instituttet for Sammenlignende

569

Kulturforskning. ser. B. no. 38.

570

571

Frei, B., 1959. Die Ausgrabungen auf der Mottata bei Ramosch im Unterengadin 1956-1958. Jahrbuch

572 der Schweizerischen Gesellschaft für Urgeschichte 47, 1958/59, 34-43.

573

574

Gat, J. R., 1980. The isotopes of hydrogen and oxygen in precipitation. In: Fritz, P., Fontes,

575

J.-C. (Eds.), Handbook of Environmental Isotope Geochemistry. The Terrestrial Environment

576

vol. 1. Elsevier, Amsterdam, pp. 21-42.

577

578

Gfeller, C., Oeschger, H., Schwarz, U., 1961. Bern Radiocarbon Dates II. Radiocarbon 3, 15-25.

579

580

Giguet-Covex, C., Pansu, J., Arnaud, F., Rey, P.-J., Griggo, C., Gielly, L. et al. 2014. Long livestock

581 farming history and human landscape shaping revealed by lake sediment DNA. Nature

582 Communications 5.

583

584

Gleirscher, P., 1985. Almwirtschaft in der Urgeschichte? Der Schlern 59, 116-124.

585

586

Gleirscher, P., 1992. Die Laugen-Melaun-Gruppe. In: Zemmer-Plank, L., (Ed.), Kult der Vorzeit in den Alpen. Opfergaben, Opferplätze, Opferbrauchtum. Innsbruck/Bozen, pp. 117-134.

Gleirscher, P., 1997. Wider den Hirten »Ötzi«. Schlern 71, 223-232.

590

Gleirscher, P., 2010. Hochweidenutzung oder Almwirtschaft? Alte und neue Überlegungen zur Interpretation urgeschichtlicher und römerzeitlicher Fundstellen in den Ostalpen. In: Mandl, F., 
Stadler, H. (Eds.), Archäologie in den Alpen. Alltag und Kult. Haus i.E. Austria: ANISA, Verein für alpine Forschung, pp. 43-62.

Gobet, E., Tinnner, W., Hochuli, P.A., Leeuwen, J.F.N., van, Ammann, B., 2003. Middle to Late Holocene vegetation history of the Upper Engadin (Swiss Alps): the role of man and fire. Vegetation History and Archaeobotany 12, 143-163.

Grant, A., 1978. Variation in dental attrition in mammals and its relevance to age estimation. In: Brothwell, D.R., Thomas, K.D., Clutton-Brock, J. (Eds.), Research Problems in Zooarchaeology. Occasional Publication 3. Institute of Archaeology, London, pp. 103-106.

Greenfield, H.J., 2010. The Secondary Products Revolution: the past, the present and the future. World Archaeology 42, 29-54.

Habermehl, K.-H., 1975. Die Altersbestimmung bei Haus- und Labortieren. Parey, Hamburg, Berlin. Haak, W., Brandt, G., de Jong, H.N., Meyer, C., Ganslmeier, R., Heyd, V., Hawkesworth, C., Pike, A.W., Meller, H., Alt, K.W., 2008. Ancient DNA, Strontium isotopes, and osteological analyses shed light on social and kinship organization of the Later Stone Age. Proceedings of the National Academy of Sciences, 105(47), pp.18226-18231.

Hafner, A., 2015. Schnidejoch und Lötschenpass. Archäologische Forschungen in den Berner Alpen. 2 Volumes. Archäologischer Dienst Bern, Bern.

Henton, E., 2012. The combined use of oxygen isotopes and microwear in sheep teeth to elucidate seasonal management of domestic herds: the case study of Çatalhöyük, central Anatolia. Journal of Archaeological Science 39, 3264-3276.

Hess, T., Reitmaier, T., Jochum Zimmermann, E., Balmer, A., Dobler, I., Della Casa, P., 2010. Leventina, prähistorische Siedlungslandschaft. Archäologischer Survey im alpinen Tessintal und entlang der Gotthardpassroute 2007/2008: kommentierter Katalog. Jahrbuch Archäologie Schweiz 93, 173-193.

Hillson, S., 2005. Teeth. Cambridge University Press, Cambridge.

Hoppe, K.A., Koch, P.L., Furutani, T.T., 2003. Assessing the preservation of biogenic strontium in fossil bones and tooth enamel. International Journal of Osteoarchaeology 13, 20-28. 
Julien, M., Bocherens, H., Burke, A., Drucker, D.G., Patoumathis, M., Krotova, O., Péan, S., 2012. Were European steppe bison migratory? 18O, 13C and Sr intra-tooth isotopic variations applied to a palaeoethological reconstruction. Quarternary International 271, 106-119.

\section{Kossack, G., 2002. Der zentrale Alpenraum während der Bronze- und vorrömischen} Eisenzeit - Institutionen, Sachbesitz und religiöse Ausdrucksformen. In: Zemmer-Plank, L., (Ed.), Kult der Vorzeit in den Alpen. Opfergaben, Opferplätze, Opferbrauchtum. Innsbruck/Bozen, pp. 285340.

Kothieringer, K., Walser, C., Dietre, B., Reitmaier, T., Haas, J.N., Lambers, K., 2015. High impact: early pastoralism and environmental change during the Neolithic and Bronze Age in the Silvretta Alps (Switzerland/Austria) as evidenced by archaeological, palaeoecological and pedological proxies. Zeitschrift für Geomorphologie 59 (Suppl. 2), 177-198.

Knipper, C., 2011. Die räumliche Organisation der linearbandkeramischen Rinderhaltung: naturwissenschaftliche und archäologische Untersuchungen. BAR International Series 2305. Archaeopress, Oxford.

Kutschera, W., Müller, W., 2003. "Isotope language'” of the Alpine Iceman investigated with AMS and MS. Nuclear Instruments and Methods in Physics Research B 204, 705-719.

Lewis, J., Coath, C.D., Pike, A.W.G., 2014. An improved protocol for ${ }^{87} \mathrm{Sr} /{ }^{86} \mathrm{Sr}$ by laser ablation multicollector inductively coupled plasma mass spectrometry using oxide reduction and a customised plasma interface. Chemical Geology 390, 173-181.

Lippert, A., Gostner, P., Egarter Vigl, E., Pernter, P., 2007. Vom Leben und Sterben des Ötztaler Gletschermannes. Germania 85, 1-21.

Makarewicz, C., Tuross, N., 2012. Finding fodder and tracking transhumance: Isotopic detection of goat domestication processes in the Near East. Current Anthropology 53(4), 495-505.

Marzatico, F., 2007. La frequentazione dell’ ambiente montano nel territorio atesino fra l’età del Bronzo e del Ferro: alcune considerazioni sulla pastorizia transumante e "l'economia di malga". Preistoria Alpina 42, 163-182.

Marzatico, F., 2009. Le plus ancien pastoralisme en «territoires extremes» des alpes italiennes centreorientales. Le Globe 149, 117-136. 
Montgomery, J., 2010. Passports from the past: investigating human dispersals using strontium isotope analysis of tooth enamel. Annals of human biology, 37(3), pp.325-346.

Migliavacca, M., 2015. Tra Età del bronzo ed Età del ferro nelle Prealpi venete occidentali: alla scoperta dei diversi tipi di sfruttamento dei paessagi montani. In: Leonardi, G., Vincenzo, T., (Eds.), Preistoria e Protostoria del Veneto. Studi di Preistoria e Protostoria 2, Firenze, pp. 479-485.

Moe, D., van der Knaap, W.O., 1990. Transhumance in Mountain Areas: Additional Interpretation of Three Pollen Diagrams from Norway, Portugal and Switzerland. In: Moe, D., Hicks, S. (Eds.), Impact of Prehistoric and Medieval Man on the Vegetation: Man at the Forest Limit. PACT 31. Strasbourg, 91-103.

Moe, D., Fedele, F.G., Maude, A.E., Kvamme, M., 2007. Vegetational changes and human presence in the low-alpine and subalpine zone in Val Febbraro, upper Valle di Spluga (Italian central Alps), from the Neolithic to the Roman period. Vegetation History and Archaeobotany 16, 431-451.

Müller, W., Fricke, H., Halliday, A.N., McCulloch, M.T., Wartho, J.A., 2003. Origin and Migration of the Alpine Iceman. Science 302, 862-866.

Nehlich, O., Montgomery, J., Evans, J., Schade-Lindig, S., Pichler, S.L., Richards, M., Alt, K.W., 2009. Mobility or migration: A case study from the Neolithic settlement of Nieder-Mörlen (Hesse, Germany). Journal of Archaeological Science 36, 1791-1799.

Nicolussi, K., 2012. Jahrringdaten zur Früh- und mittelholozänen Baumgrenze in der Silvretta. In: Reitmaier, T. (Ed.), Letzte Jäger, Erste Hirten. Hochalpine Archäologie in der Silvretta. Amt für Kultur, Archäologischer Dienst Graubünden, Chur, pp. 87-100.

Niederstätter, A., 1999. Bemerkungen zur Rinderhaltung im vorindustriellen Vorarlberg. Eine erste Bestandsaufnahme. Montfort, Vierteljahresschrift für Geschichte und Gegenwart Vorarlbergs 51, 118128.

Oeggl, K., Schmidl, A., Kofler, W., 2009. Origin and seasonality of caprine dung from the discovery site of the Iceman (Eastern Alps). Vegetation History and Archaeobotany 18, 37-46.

Oeggl, K., Kofler, W., Schmidl, A., Dickson, J.H., Egarter Vigl, E., Gaber, O., 2007. The reconstruction of the last itinerary of »Ötzi«, the Neolithic Iceman, by pollen analyses from sequentially sampled gut extracts. Quarternary Science Review 26, 853-861. 
Oelze, V.M., Nehlich, O., Richards, M.P., 2012. "There's no place like home" - No isotopic evidence for mobility at the Early Bronze Age cemetery of Singen, Germany. Archaeometry 54, 752-778.

Patzelt, G., 2013. Datierung von Feuerstellen in prähistorischen Hirtenhütten im Waldgrenzbereich ostalpiner Gebirgsgruppen. Praearchos 4. Innsbruck, 1-74.

Pearson, J., Buitenhuis, H., Hedges, R.E.M., Martin, L., Russell, N., Twiss, K., 2007. New light on early caprine herding strategies from isotope analysis: a case study from Neolithic Anatolia. Journal of Archaeological Science 34, 2170-2179.

Planta, A., 1987. Eine wichtige Alpentransversale in ihrem Schnittpunkt mit dem untersten Engadin. In: Planta, A.,Verkehrswege im alten Rätien 3. Chur, 81-166.

Plüss, P., 2011. Die bronzezeitliche Siedlung Cresta bei Cazis (GR): Die Tierknochen. Zürich.

Primas, M., 1998. Der bronzezeitliche Landausbau in den Alpen. In: B. Hänsel (Ed.), Mensch und Umwelt in der Bronzezeit Europas. Verlag Marie Leidorf, 355-365.

Primas, M., 2009. Nicht nur Kupfer und Salz: Die Alpen im wirtschaftlichen und sozialen Umfeld des 2. Jahrtausends. In: Bartelheim, M., Stäuble, H. (Eds.), Die wirtschaftlichen Grundlagen der Bronzezeit Europas. Forschungen zur Archäometrie und Altertumswissenschaft 4. Rahden/Westf., 189-211.

Putzer, A., 2009. Eine prähistorische Almhütte auf dem Schwarzboden im Mandeidtal, Südtirol/Vinschgau. Archaeologia Austriaca 93, 33-43.

Putzer, A., 2013. Königinnen der Almen. Prähistorische Weidewirtschaft im Schnalstal. Der Schlern $87,4-31$.

Putzer, A., Festi, D., 2014. Nicht nur Ötzi?-Neufunde aus dem Tisental (Gem. Schnals/Prov. Bozen). Praehistorische Zeitschrift 89, 55-71.

Putzer, A., Festi, D., Oeggl, K., 2016. Was the Iceman really a herdsman? The development of a prehistoric pastoral economy in the Schnals Valley. Antiquity 90, 319-336.

Raba, A., 1996. Historische und landschaftsökologische Aspekte einer inneralpinen Terrassenlandschaft am Beispiel von Ramosch. Unpublished Dissertation. Freiburg/B. 
743 Rageth, J., 2010. Der Siedlungsprozess im bündnerischen Alpenraum während der Bronze- und 744 Eisenzeit und einige Aspekte zu Verbindungswegen. In: Dal Ri, L., Gamper, P., Steiner, H. (Eds.),

745 Höhensiedlungen der Bronzezeit und Eisenzeit. Kontrolle der Verbindungswege über die Alpen.

746 Forschungen zur Denkmalpflege in Südtirol 4, 381-395.

747

748

749

750

751

752

753

754

755

756

757

758

759

760

761

762

763

764

765

766

767

768

769

770

771

772

773

774

775

776

777

Reimer, P.J., Bard, E., Bayliss, A., Beck, J.W., Blackwell, P.G., Bronk Ramsey, C., Grootes, P.M., Guilderson, T.P., Haflidason, H., Hajdas, I., HattŽ, C., Heaton, T.J., Hoffmann, D.L., Hogg, A.G., Hughen, K.A., Kaiser, K.F., Kromer, B., Manning, S.W., Niu, M., Reimer, R.W., Richards, D.A., Scott, E.M., Southon, J.R., Staff, R.A., Turney, C.S.M., van der Plicht, J., 2013. IntCal13 and Marine13 Radiocarbon Age

Calibration Curves 0-50,000 Years cal BP. Radiocarbon 55, 1869-1887.

Reitmaier, T., 2010. Auf der Hut - Methodische Überlegungen zur prähistorischen Alpwirtschaft in der Schweiz. In: Mandl, F., Stadler, H. (Eds.), Archäologie in den Alpen. Alltag und Kult. Verein für Alpine Forschung, Innsbruck, pp. 219-238.

Reitmaier, T., 2012. Letzte Jäger, erste Hirten. Alpine Archäologie in der Silvretta 2007-2012. In: Reitmaier, T. (Ed.), Letzte Jäger, erste Hirten. Hochalpine Archäologie in der Silvretta. Amt für Kultur, Archäologische Dienst Graubünden (ADG), Chur, pp. 9-65.

Reitmaier, T., Lambers, K., Walser, C., Zingman, I., Haas, J.N., Dietre, B., Reidl, D., Hajdas, I., Nicolussi, K., Kathrein, Y., Naef, L., Kaiser, T., 2013. Alpine Archäologie in der Silvretta. Archäologie Schweiz 36, 4-15.

Riedel, A., Tecchiati, U., 2001. Settlements and economy in the Bronze and Iron Age in TrentinoSouth Tyrol. Notes for an archaeozoological model. Preistoria Alpina 35, 105-113.

Röpke, A., Stobbe, A., Oeggl, K., Kalis, A.J., Tinner, W., 2011. Late-Holocene land-use history and environmental changes at the high altitudes of St Antönien (Switzerland, Northern Alps): Combined evidence from pollen, soil and tree-ring analyses. Holocene 21, 485-498.

Röpke, A., Krause, R., 2013. High-montane-subalpine soils in the Montafon Valley (Austria, northern Alps) and their link to land-use, fire and settlement history. Quaternary International 308-309, 178189. 
SBL, 2008. Schweizerisches Bundesamt für Landestopografie. www.map.geo.admin.ch (Geocatalog: Geological Map 500, last accessed 30 November 2016).

SBL, 2014. Schweizerisches Bundesamt für Landestopografie. www.map.geo.admin.ch (Geocatalog: GeoCover - Geological Vector Datasets, last accessed 30 November 2016).

Schibler, J., Breitenlechner, E., Deschler-Erb, S., Goldenberg, G., Hanke, K., Hiebel, G., Hüster Plogmann, H., Nicolussi, K., Marti-Grädel1, E., Pichler, S., Schmidl, A., Schwarz, S., Stopp, B., Oeggl, K., 2011. Miners and mining in the Late Bronze Age: a multidisciplinary study from Austria. Antiquity 85, 1259-1278.

Schwörer, C., Colombaroli, D., Kaltenrieder, P., Rey, F., Tinner, W., 2015. Early human impact (5000-3000 BC) affects mountain forest dynamics in the Alps. Journal of Ecology 103, 281-295.

Spindler, K., 2005. Der Mann im Eis und das Wanderhirtentum. In: Holzer, J., Walde, E. (Eds.), Brüche und Brücken. Kulturtransfer im Alpenraum von der Steinzeit bis zur Gegenwart. Transfer 57. Wien/Bozen, pp. 22-41.

Stauffer-Isenring, L., 1983. Die Siedlungsreste von Scuol-Munt Baselgia (Unterengadin GR). Antiqua 9. Archäologie Schweiz, Basel.

Steiner, H. (Ed.), 2010. Alpine Brandopferplätze. Archäologische und naturwissenschaftliche Untersuchungen / Roghi Votivi Alpini. Archeologia e scienze naturali. Trento.

Stopp, B. 2015. Animal husbandry and hunting activities in the Late Bronze Age Circum-Alpine Region. In: Menotti, F. (Ed.), The end of the lake-dwellings in the Circum-Alpine region. Oxford, pp. 179-210.

Tinner, W., Theurillat, J.-P., 2003. Uppermost Limit, Extent, and Fluctuations of the Timberline and Treeline Ecocline in the Swiss Central Alps during the Past 11,500 Years. Arctic, Antarctic, and Alpine Research 35, 158-169.

Tinner, W., Conedera, M., Ammann, B., Lotter, A.F., 2005. Fire ecology north and south of the Alps since the last ice age. The Holocene 15, 1214-1226.

Valenzuela, S., Jiménez-Manchón, S., Evans, J., López, D., Jornet, R., Albarella U, 2016. Analysis of seasonal mobility of sheep in Iron Age Catalonia (north-eastern Spain) based on strontium and oxygen 

836.

Veizer, J., Ala, D., Azmy, K., Bruckschen, P., Buhl, D., Bruhn, F., Carden, G.A.F., Diener, A.,

819 Ebneth, S., Godderis, Y., Jasper, T., Korte, C., Pawellek, F., Podlaha, O.G., Strauss, H., 1999.

${ }^{87} \mathrm{Sr} /{ }^{86} \mathrm{Sr}, \delta^{13} \mathrm{C}$ and $\delta^{18} \mathrm{O}$ evolution of Phanerozoic seawater. Chemical Geology 161, 59-88.

Walsh, K., Mocci, F., 2011. Mobility in the Mountains: Late Third and Second Millennia Alpine

Societies' Engagements with the High-Altitude Zones in the Southern French Alps. European Journal of Archaeology 14, 88-115.

Walsh, K., Court-Picon, M., de Beaulieu, J.-L., Guiter, F., Mocci, F., Richer, S. et al. 2014. A historical ecology of the Ecrins (Southern French Alps): Archaeology and palaeoecology of the Mesolithic to the Medieval period. Quaternary International 353, 52-73.

Weiss, R., 1992. Das Alpwesen Graubündens. Wirtschaft, Sachkultur, Recht, Älplerarbeit und Älplerleben. Reprint Chur.

Willmes, M., Kinsley, L., Moncel, M.H., Armstrong, R.A., Aubert, M., Eggins, S. and Grün, R., 2016. Improvement of laser ablation in situ micro-analysis to identify diagenetic alteration and measure strontium isotope ratios in fossil human teeth. Journal of Archaeological Science, 70, pp.102-116.

Würgler, F.E., 1962. Veränderungen des Haustierbestandes während der Bronze- und

Eisenzeit in zwei schweizerischen «Melauner» Stationen, Montlingerberg und Mottata Ramosch. $1177-1187$.

Zazzo, A., 2014. Bone and enamel carbonate diagenesis: A radiocarbon prospective. Palaeogeography, Palaeoclimatology, Palaeoecology 416, 168-178.

Zoller, H., Erny-Rodman, C., 1994. Epochen der Landschaftsentwicklung im Unterengadin. 581. 
Figure 1:

Aerial image and geological map of the study area. Source of aerial imagery and digital terrain model:

857

858

859

860

861

862

863

864

865

866

867

868

869

870

871

872

873

874

875

\section{Figure 2:}

Tooth enamel ${ }^{87} \mathrm{Sr} /{ }^{86} \mathrm{Sr}$ for cattle (Bos taurus) from Ramosch-Mottata (RMO), measured by LA-MCICP-MS. All samples are taken from M3, except for sample RMO 1.2.1 (M2). Black lines represent the means of 10 measurements including $2 \sigma$ error bars marked in grey. The shaded bar indicates the "on-site" ${ }^{87} \mathrm{Sr} /{ }^{86} \mathrm{Sr}$ ranging from 0.70809 to 0.70850 . Given dates are based on calibrated radiocarbon measurements $(2 \sigma)$ and organized by chronology according to table 2 .

\section{Figure 3:}

Boxplot diagram based on individual ${ }^{87} \mathrm{Sr} /{ }^{86} \mathrm{Sr}$ measurements for cattle (Bos taurus) from RamoschMottata, GR (Switzerland), organized by chronology according to table 2 (box: interquartile range, central line: mean, cross: median, whisker: $\pm 1.5 \mathrm{IQR}$ (inter quartile range), circle: outlier, star: extreme outlier).

Figure 4: $87 \mathrm{Sr} / 86 \mathrm{Sr}$ vs 1/Sr for dentine and enamel samples. We use the mean ${ }^{88} \mathrm{Sr}$ beam (V) as a proxy for $\mathrm{Sr}$ concentration. While this reflects the relative concentrations, without a matrix matched sample, we cannot reliably convert this to absolute concentrations.

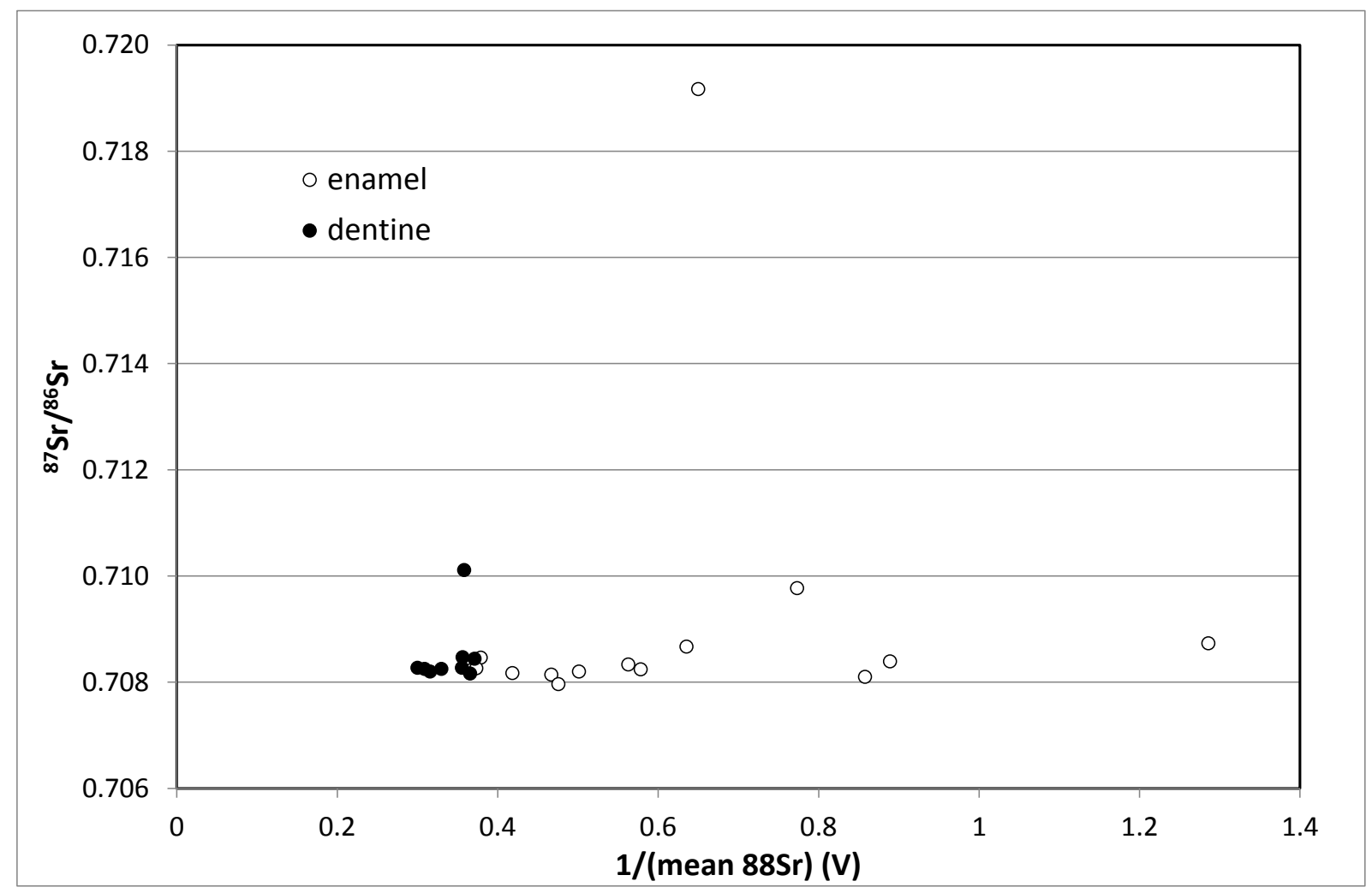


879 Figure 5: ${ }^{87} \mathrm{Sr} /{ }^{86} \mathrm{Sr}$ for dentine-enamel pairs. In theory, as diagenesis progresses, dentine values should tend towards the diagenetic end member which is the case for all but sample 13. (Sample

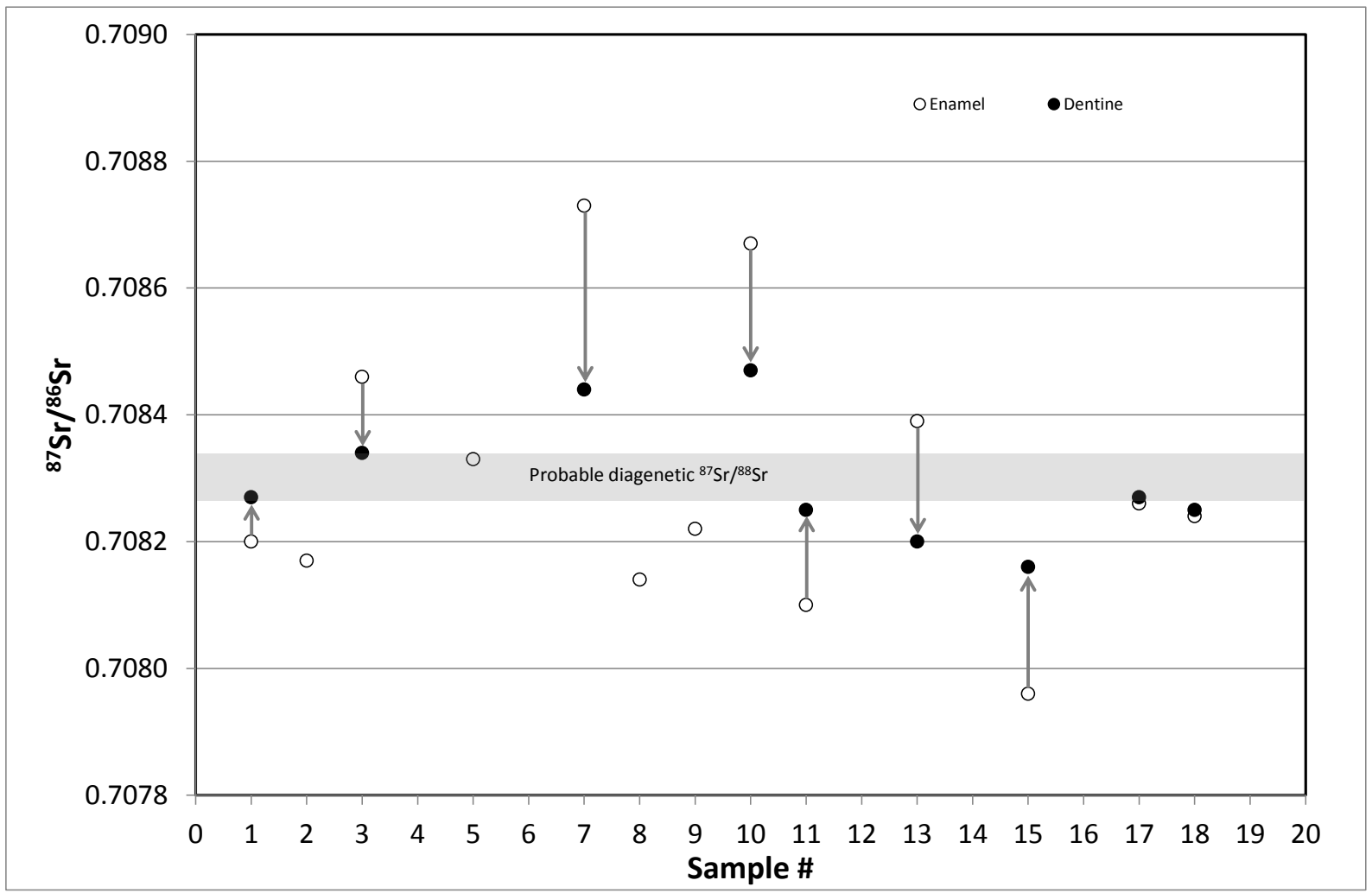

\section{Figure 6:}

885 A: The mobility of alpine herders with non-dairying animals (modified from Carrer 2016a) and spatial distribution of archeological sites in the Silvretta Alps (above 2000 m a.s.1.) during the Bronze Age 2200-800 cal. BC, red dots), based on radiocarbon measurements.

B: The mobility of alpine herders with dairying animals (modified from Carrer 2016a) and spatial distribution of archeological sites in the Silvretta mountain range (above $2000 \mathrm{~m}$ a.s.1.) during the Iron Age (800-15 cal. BC, red squares), based on radiocarbon measurements. Source of Digital Terrain Model: ASTER GDEM (ASTER GDEM is a product of METI and NASA). Source of country borders: http://diva-gis.org/gdata.

Table 1:

Radiocarbon dates of known archeological sites in the Silvretta Alps (above 2000 m a.s.1.). The site numbers correspond to the numbers shown in Fig. 6. Analyses were performed on charcoal at the Laboratory for Ion Beam Physics, ETH Zürich. Calibration: OxCal v4.2 Bronk Ramsey (2016); IntCal 13 atmospheric curve (Reimer et al., 2013). 
900 Table 2:

901 Radiocarbon dates of cattle remains (Bos taurus) from Ramosch-Mottata (RMO). Analyses were

902 performed at the Laboratory for Ion Beam Physics, ETH Zürich. Calibration: OxCal v4.2 Bronk

903 Ramsey (2013); IntCal 13 atmospheric curve (Reimer et al. 2013). The attribution to one of the five

904 stratigraphic units derives from the inventory number (Inv. no) after Würgler (1962).

905

906 Table 3:

907 Archeozoological and ${ }^{87} \mathrm{Sr} /{ }^{86} \mathrm{Sr}$ data (mean, minimum, maximum, range of tooth enamel and mean of

908 dentin) for cattle (Bos taurus) from Ramosch-Mottata (RMO). The approximate age at death (Age) is 909 indicated in years. 